\title{
Free Access to the Documents and Information of the EU Institutions from the Point of View of Czech Legislation
}

\author{
Petr Kolman* \\ JIŘÍ KOLMAN**
}

\begin{abstract}
Free access to information is considered to be one of the most important fundamental political rights of citizens. Free access to information has a long history originating in Sweden in the 18th century and has since then been incrementally constitutionalised in most of the democratic countries. It is worth studying the fact that legislation regulating this question in European Union legal systems, and in the Czech Republic as well, started much later - fifteen years ago at the beginning of the millennium. Even though the age of both the acts - EU (the Regulation of the European Parliament and the Council (EC) No. 1049/2001 of 30 May 2001 regarding public access to European Parliament, Council and Commission documents) and Czech (the Act (CZ) on Free Access to Information No. 106/1999) is the same, the legislation itself differs significantly and they both have legal shortcomings. The analysis of the EU legislation granting free access to information of the EU institutions from the Czech perspective brings interesting and inspiring ideas for reforms - especially of the EU legislation.

Keywords: Free access to the documents and information of the EU Institutions; the Regulation of the European Parliament and the Council (EC) No. 1049/2001 of 30 May 2001 regarding public access to European Parliament, Council and Commission documents; the Act (CZ) on Free Access to Information No. 106/1999; de lege ferenda of the free access to the documents and information of the EU Institutions; transparency of the public service; the right to information.
\end{abstract}

\section{BACKGROUND INFORMATION - THE CZECH AND EU PERSPECTIVE ${ }^{1,2}$}

The right to information in the constitutional order in the Czech Republic is among the political rights guaranteed by the Charter of Fundamental Rights and Freedoms. Thus, the right to information is a constitutional right in the Czech Republic, i.e. the right of the

* Lawyer and juristic researcher focusing on free access to information legislation at the Faculty of Law, Masaryk University, Veveri 70, 611 80, Brno, the Czech Republic, member of the analytic group of the Office for the Protection of Competition and member of the analytic group of the Czech National Bank. E-mail: Petr.Kolman@law.muni.cz

** Lawyer, PhD and doctoral researcher at the Faculty of Law, Masaryk University in Brno (EU law), scientific secretary at the Global Change Research Institute of the Czech Academy of Sciences. E-mail: kolman.j@czechglobe.cz

1 We have adopted many ideas presented in this article in various discussions with many people, some of them directly involved in the scope of the agenda, either of form the EU institutions (mainly EU Council, European Commission, European Parliament, national and international NGOs (e.g. Otevřená společnost o. p. s., Access Info Europe) focusing on the transparency of the public service and direct users (individuals, legal persons and groups of activists) of the free access to information legislation. Since some would prefer to remain anonymous, we would like to thank all of them at least in this way. All errors, of course, are our own responsibility.

2 This work was supported by the Ministry of Education, Youth and Sports of CR within the National Sustainability Program I (NPU I), grant number LO1415, and thanks to the COST project CA15137 European Network for Research Evaluation in the Social Sciences and the Humanities (ENRESSH). 
highest legal force (Kolman, 2010). In the case of the EU legislation the right to information does not guarantee free access to information but the European Charter of Fundamental Rights protects (article 42) and its implementing legislation provides 'only' right of access to documents.

Free access to information is interconnected with citizens and political rights. These rights are inextricably linked to human activities in governing public affairs within the state. Various states had begun to include these rights in their constitutions since the French Revolution, and they can be traced back to the Declaration of the Rights of Man and of the Citizen published in the late 18th century. In the case of the EU, which evolved from mainly an economy oriented entity into a more integrated (even partly) political union (e.g. with a directly elected European parliament with strong legislative powers), we can see shortcomings in the protection of this democratic right, and this might be one of the reasons of the general feeling of lack transparency of the life of the EU institutions. As a leading Czech constitutional law theorist, J. Filip, states, the political aspect of free access to information means the following: 'A wider concept of political rights does not include only participation in public affairs management by voting or exercise of a function or office but also what is sometimes referred to as political freedom. That is, for example, freedom of expression, right to information, freedom of association and assembly' ${ }^{3}$

The right to information is a specific right. Its peculiarity lies in the fact that it is a right per se (i.e. as such), and at the same time it must be understood as a bridge towards the exercise of other rights. Simultaneously, the right to information may be an obstacle to the exercise of other rights. The experience of the Czech legislation illustrates an even broader right to information provisions, compared to that of EU legislation, that has not fundamentally jeopardised protection of fundamental rights (e.g. personal data protection) and no specific legislative amendment of the relevant Czech legislation is needed.

For fifteen years, the Act on Free Access to Information No. 106/1999 (hereinafter Act No. 106/1999) has been part of the Czech legal order. The Act No. 106/1999 has been amended several times taking into consideration the technological development of society and the new binding international and EU legislation which, for the Czech Republic, means mainly the Aarhus Convention and the EU directives PSI (The Directive of the European Parliament and the Council 2003/98/EC of 17 November 2003 on the re-use of public sector information) and INSPIRE (The Directive of the European Parliament and the Council 2007/2/EC of 14 March 2007 on establishing an Infrastructure for Spatial Information in the European Community). The Aarhus Convention was implemented by the Statement No. 124/2004 of the Ministry of Foreign Affairs on the Convention on Access to Information, Public Participation in Decision-making and Access to Justice in Environmental Matters into the Czech legal system. In this context it is important to point out that various related legal aspects of the implementation of the international and EU legal acts in the Czech legal system are analysed by F. Křepelka. ${ }^{4}$ Krepelka deals with the clash of the secondary EU legislation implementing the international treaty signed by EU and member states that have its own implementing national legislation that was for instance passed before their EU membership (e.g. the case of Aarhus Convention) or before the EU implementing act was passed. In these cases, he concludes that national law is not applicable due to the EU law supremacy principle.

\footnotetext{
3 Filip (1997) 93.

${ }^{4}$ Křepelka (2010) 9 skk.
} 
The Regulation of the European Parliament and the Council (EC) No. 1049/2001 of 30 May 2001 regarding public access to European Parliament, Council and Commission documents (hereinafter Regulation No. 1049/2001) has been effective for a similar period of time. As the name suggests, the aim of the Regulation is to make documents accessible to key institutions of the European Union. Unlike the Czech legislation, that of the EU has never been amended, although there have been several unsuccessful legislative attempts to revise the current state by adopting a new regulation. We can conclude from this that the EU legislation is 'frozen' with regards to the technological and social development of the society of 2001 (e.g. at that time there was no political discussion about open public data).

If we wished to make assessing a pre-conclusion before reading the analysis below, we could say that the current state of the Czech Act No. 106/1999 (compared with the still valid EU regulation) could have been much worse. It does not matter if we look at it from the perspective of the individual citizen, civil society (for example, through the lens of activist associations) or from the other side of the barricade, i.e. the public institutions as entities obliged to provide information.

The following analysis of the European regulation based on the comparison of the Czech legislation shows that the frequently criticized democratic deficit in the functioning of EU institutions is apparent here as well. Despite the fact that the EU institutions often critically comment on the institutions of member countries and their domestic practice (e.g. in the form of regular evaluation of the European Semester), the current Regulation No. 1049/2001 is in some respects alienated, by its wording, to the democratic principles of the transparent functioning of the EU public institutions. Certain shortcomings in the EU legislation are discussed in the text below.

\section{THE MAIN PURPOSE OF THE REGULATION, ITS BENEFICIARIES AND SCOPE}

Articles 1 and 2 define the purpose of the Regulation, beneficiaries and the scope of the Regulation.

According to Art. 1, the purpose of the Regulation is the following:

a) To define the principles, conditions, and limits on grounds of public or private interest governing the right of access European Parliament, Council and Commission (hereinafter referred to as 'institutions') documents provided for in Article 255 of the EC Treaty in such a way as to ensure the widest possible access to documents.

b) To establish rules ensuring the easiest possible exercise of this right.

c) To promote good administrative practice on access to documents.

It is surprising that the very first article of the regulation does not expressly take into account other EU institutions, for example The European Economic and Social Committee (hereinafter referred to as 'EESC'), the Committee of the Regions (hereinafter referred to as ' $\mathrm{CR}$ ') or EU agencies such as the European Foundation for the Improvement of Living and Working Conditions (hereinafter referred to as 'Eurofound'), founded as early as 1975. However, in reality the Regulation has been applied to EU agencies as well. ${ }^{5}$

The purpose of the regulation is defined quite clearly and easy to understand, supporting the efforts to make the functioning of EU institutions transparent to the general public (the main purpose and task of this regulation) while respecting other public and 
private interests. This 'proportional approach' has in mind these interests (i.e. transparency and efficiency of the functioning of the EU institutions) which have been used by the ECJ (e.g. the cases T-42/05 and T-2/03). Both judgments cited above deal with the question of reconciling the interests of the applicant (e.g. the request for a large number of documents requiring a laborious search and preparation with regard to the protection of personal data) and the interests of good administration (not to paralyze the operation of the institution by applications). Judgments in their reasoning generally state that the institutions should, in such cases, seek a solution acceptable to both parties. ${ }^{6}$ It is a pity that the order of the enumerated purposes is not 'prioritized' in a different way in the Regulation, i.e. from the most important one in terms of this Regulation (the order of the points should rather be: b), c) and a)). In our opinion, it would be better to speak of the Regulation first of access to documents and then to consider the setting of legal boundaries of the 'EU wobbing'. This would mean helping the potential document seeker, by placing emphasis this way; it enables us to understand what the main purpose of the Regulation is.

The issue of the authorized persons and the territory covered by the Regulation is defined in Article 2. The applicants, i.e. persons with active legitimization, are defined quite controversially as 'any citizen of the Union, and any natural or legal person residing or having its registered office in a Member State that has a right of access to documents of the institutions, subject to the principles, conditions and limits defined in this Regulation.'

We consider the above mentioned provision questionable on the grounds that the group of potential applicants is very limited. Even the Czech legislation defines potential applicants more broadly.

Terminologically, we do not consider it appropriate to use the term 'citizens' - rather, it would be preferable to use 'people' - either natural or legal ones as the term 'citizens' sounds a little archaic to the authors.

This right is, in the case of EU institutions, denied for example to entities from the candidate countries, asylum-seekers, citizens of third countries (e.g. a foreign journalist has no right to demand access to documents of EU institutions, even if they concern EU policies having an impact on third countries, such as development aid or EU trade policy), non-EU non-profit organizations, etc. Another problematic aspect is the fact that this provision can be circumvented through an intermediary, i.e. a potential applicant lacking the active legitimization may try to request a document through an EU citizen or an EU legal person. In terms of efforts to eliminate the democratic deficit in the EU and at least as a gesture (perhaps in a footnote) it would certainly be worthwhile in the future, according to the designed law, to expand the circle of potential applicants, as we know it from the Czech legislation (See Section 3, Paragraph 1, Act No. 106/1999 'The applicant for the purpose of this Act is any natural or legal person asking for information.'), to any citizen and legal person, i.e. not to restrict this right to be dependent on the condition of nationality (citizenship, residence, seat) within the EU'.

Pursuant to the second paragraph of Art. 2 of the Regulation, the 'institutions may, subject to the same principles, conditions and limits, grant access to documents to any natural or legal person not residing or not having its registered office in a Member State', but this provision unnecessarily gives the EU institutions the power to decide on the basis

6 See Case T-42/05 Rhiannon Williams v European Commission [2005] ECR II-00156, and Case T-2/03 Verein für Konsumenteninformation v. Commission of the European Communities [2005] ECR II-01121. 
of administrative discretion. This discretionary power can sometimes be associated with a lack of transparency, corruption or bullying behaviour from the part of the administrative bodies of the EU. In order to prevent such behaviour it would be worth to look over the Czech legislation regarding the definition of applicants that involve 'any natural or legal person asking for information'. In the Czech Republic, an applicant for information may be a foreigner and not only from EU countries. The applicant may also be a minor. The issue of age has not been dealt with by the European Union legislation.

The scope of application described in Art. 2 (i.e. simply said the documents held by EU institutions that may be provided to applicants) is then complimented by a definition of 'document' in Art. 3. The regulation defines a document as 'any content whatever its medium (written on paper or stored in electronic form or as a sound, visual or audio-visual recording) concerning a matter relating to the policies, activities and decisions falling within the institution's sphere or responsibility'.

In this respect, it should be noted that the Regulation does not expressly define the right to access to information, and so it cannot be induced, according to the EU case law, that the public's right to access to documents of the EU institutions, which follows from Art. 2, Para. 1 of the Regulation, entails an obligation of the EU institutions to respond to any request for information made by an individual. ${ }^{7}$ Furthermore, according to the case law of the EU, the Regulation grants access only to the existing documents which the institution has, see e.g. The judgment of the ECJ (Second Chamber) 2 October 2014, C-127/13 P, Guido Strack v European Commission. Case C-127/13 P.

\section{EXCEPTIONS DENYING ACCESS TO DOCUMENTS}

Article 4 of the Regulation lists exceptions denying access to documents where disclosure would undermine the protection of public interest (e.g. public security, defence, international relations, or the economic policy of the EU or a Member State) or the privacy and integrity of an individual. These limitations can be considered to be a standard that is also applied in other legal orders of democratic countries.

It is questionable whether denial of access to information can be argued on the grounds of protecting international relations. This is especially true in the case of documents related to the preparation of international treaties. International negotiations are de facto part of the legislative process, and this provision (Art. 4, Para. 1. a) - International relations) can be regarded as inconsistent with Art. 2, Para. 4, which emphasizes that 'in particular, documents drawn up or received in the course of a legislative process' should be directly accessible i.e. also the documents related to the preparation of international treaties - i.e. rules with the highest legal force. Due to various litigations ${ }^{8}$ and the publicized preparation of the international treaty ACTA, which was finally dismissed by the European Parliament, the European Commission is currently far more willing to disclose documents related to the preparation of international treaties. ${ }^{9}$ Despite the proclaimed willingness of the European Commission to publish documents related to the preparation of the Transatlantic Trade and

7 See e.g. Case T-264/04 WWF European Policy Programme v. Council of the European Union [2007] ECR II-00911, and Case T-214/13 Rainer Typke v. the European Commission [2013] ECLI:EU:T:2015:448.

${ }^{8}$ See e.g. Case C-280/11, The Council of the European Union v. Access Info Europe [2007] ECLI:EU:C:2013:671.

9 See e.g. Now Online - EU negotiating texts in TTIP (2015) link 1. 
Investment Agreement (hereinafter 'TTIP') with the United States, the European Commission has still been criticized for not disclosing all its documents. ${ }^{10}$ The TTIP can thus be regarded as a litmus test of the current approach of the European Commission and other EU institutions involved in the preparation and approval of this agreement, to the issue of making related documents accessible (e.g. proposals of various interested economic groups). Currently, as for the designed law, it is not probably legally sustainable to use protection of international relations as a reason for denying access to information since in many cases it is the legislative process (preparing and concluding international agreements) which deserves transparent negotiations and democratic control by the public.

Another interesting aspect of Art. 4 is the denial of access to documents with regard to the protection of personal data. This restriction contained in Art. 4, Para. B) is understandable and it is a standard part of other legislation. However, this provision is interesting in terms of comparison between the US and the EU legislation governing the protection of personal data. The general approach of the legislation regulating the protection of personal data is different in the EU and in the US. Under the US law, protection of privacy in fact constitutes a protection of an individual against the state, while in the EU, protection is based on the intention of an individual to control his/her public image, i.e. not only in relation to the state authority but also in relation to the general public. ${ }^{11}$ This difference in perception of privacy is probably based on different historical experiences. Europe had to cope with totalitarian regimes abusing the personal data of their citizens. Therefore, it is clear that the reluctance to share personal data with state (public) authorities is accepted by the general public in the EU, even though in some cases (e.g. salaries of top politicians and officials) this reluctance is being gradually abandoned. Because of the legitimate democratic control it would be worth, in the case of Article 4, rephrasing the restriction of access so that the public could have access to both documents and information relating to the management of EU institutions (e.g. the issue of the remuneration of senior officials of the EU institutions, their professional qualifications, etc.).

The provision of Art. 4, Para. 2, establishing that in cases where disclosure would undermine the protection of 'legal advice' the access may be denied seems to be quite an indefinite reason to a certain extent. A concept like this or a similar one is unknown to the Czech legislation - Act No. 106/1999 - and can be considered quite vague. In our view, it is obvious that personal data concerning the persons in question or the prepared information may not be disclosed due to the other provisions of Art. 4. Legal advice may include anything that a private individual, amongst others, provides to an institution or its employees. For example, a private individual will want to lobby for a change in the EU legislation and will provide an official of the European Commission with his own proposal, which will be then incorporated into the proposal of the Commission. If a third party (i.e. a non-profit organization focused on the transparent functioning of the EU institutions) wanted to see that document, this legitimate request could be rejected with regard to protection of 'legal advice'. Thus, it would be advisable to abolish this particular reason for denial of access to information.

10 See e.g. WikiLeaks nabízí 100 tisíc dolarů za podrobnosti k TTIP. Přispěl i Varufakis' [WikiLeaks offers $\$ 100,000$ for details of TTIP. A contribution by Varufakis] (2015) link 2.

11 Whitman (2008) 1151-221; Novák (2012) 6. 


\section{APPLICATIONS AND THEIR HANDLING}

Articles 6 and 8 regulate the form of applications for documents and their processing. As to formal requirements of the application, the wording of the Regulation is rather benevolent and does not even require information about the applicant that might identify him/her in terms of the criteria for an 'authorized person' (nationality, address, etc.) specified in Art. 2 of the Regulation. Article 7 then obliges the addressed authority to send an acknowledgment of the receipt of the application. The authors of this text must say that based on their personal experience (since 2011 the authors have posed at least five requests for information) with making a request at European Union institutions such a request has never been immediately dealt with (in the words of the Regulation 'without delay'). Nor has an acknowledgment of receipt, as required under Art. 7, Para. 1, ever been sent, which affected the legal certainty of the authors.

It is also interesting that the issue of language has not been thoroughly dealt with. Article 7 of the Regulation guarantees the possibility of filing an application in any official language of the European Union but it does not clearly specify whether the response and the document must be provided in the language of the application. Only Art. 10, Para. 3 states that 'documents shall be supplied in an existing version and format'. The fact that the documents are supplied in an existing version according to the EU case law also means that an application for access, which would lead an EU institution to create a new document, even on the basis of the elements that are already contained in the existing documents in its possession, is not an application for partial access - see, among others, the judgment of ECJ (Third Chamber) 26 October 2011, Case T-436 / 09, Julien Dufour v European Central Bank.

Art. 7 also lists deadlines for processing applications. 'Within 15 working days from registration of the application, the institution shall either grant access to the document requested and provide access in accordance with Article 10 within that period or, in a written reply, state the reasons for the total or partial refusal and inform the applicant of his or her right to make a confirmatory application in accordance with paragraph 2 of this Article' (i.e. pursuant to Art. 7, Para. 2: 'In the event of a total or partial refusal, the applicant may, within 15 working days of receiving the institution's reply, make a confirmatory application asking the institution to reconsider its position.'). The deadline of 15 working days for providing the requested documents may be considered quite generous for EU institutions. This is in contrast to the Czech Act No 106/1999, which establishes 15 days (i.e. calendar days), and we also have to bear in mind that EU institutions have fewer working days than the institutions of the Czech Republic. For example, in 2015 there were 10 days of public holidays falling on days other than Saturdays or Sundays, whereas in the case of the European Commission the number of such non-working days was 17. In light of the fact that potential applicants may need to obtain documents from EU institutions with a view to necessary administrative procedures (e.g. for the evidence or arguments in the appeal) it is then justifiable to request shortening this period to 10 or less working days. Sometimes someone may need a document from an EU authority for administrative proceedings with the EU institutions or in a member state, or democratic control (e.g. at the time of the European Parliament elections) may be paralyzed by careful adherence to statutory deadlines. The same applies to the work of journalists reporting on the agenda of the European Union who are often dependent on the information provided by EU institutions. 
Art. 8 imposes an obligation on the addressed institution in the event of a total or partial refusal to inform the applicant of the remedies open to him, namely of instituting court proceedings against the institution or making a complaint to the Ombudsman, under the conditions laid down in Articles 230 and 195 of the EC Treaty. Although the preamble mentions a two-stage administrative procedure, the text of the Regulation in fact does not enable a two-instance type of proceedings to which we are accustomed in the Czech Republic, and thus the applicant does not have a legally established possibility to appeal to a higher administrative authority or a superior person, but he or she is immediately left by the legislation with the judicial proceedings or a complaint to the Ombudsman. Compared with the Czech legislation, denied applicants thus have a smaller choice of legal tools to use and current EU tools do not provide an easy (less time-consuming, cheaper and effortless) way that might be reached by the possibility of use of administrative appeal to a superior administrative body. The authors of this text must also say that so far they have not encountered a response of an EU institution which would include guidance on the options of reviewing the response of an EU institution (there was no difference between a response to an application or a refusal). The absence of guidance on appeals for the applicant in the case of a negative response from the European Commission has already been pointed out in the above mentioned judgment of the General Court in Case T-214/13. However, the absence of guidance on appeals was not considered by the Court as relevant for this judicial proceeding.

A note on the application practice: Answers to questions in the case of the European Commission give an impression of disorder as different departments deal with applications in different ways. It is obvious that the application and interpretation of the Regulation may vary in practice. The issue of the notion of 'interpretation' was very well analysed recently by A. Paprocka and M. Ziółkowski ${ }^{12}$ in the case of unified interpretation of the Convention for the Protection of Human Rights and Fundamental Freedoms. Neither applications for information sent to the press departments of the individual general directorates were administered in the same manner, and they were rather chaotically forwarded to the ad hoc chosen departments or officials. This experience of ours (based on the above mentioned authors' information requests) from the current application practice of the EU institutions disrupts our confidence in the legislation concerned and in the correct adjustment of its control mechanisms. However, in the case of the Czech Republic, it must be admitted that the uniform legal and judicial interpretation is challenging as well. Very good examples of the analysis based on the Czech Constitutional Court's judgments of the general reasons of different interpretation and application of the EU legislation in the case of the Czech judicial and legal systems can be found in J. Komárek ${ }^{13}$ and P. Molek. ${ }^{14}$

\section{TREATMENT OF SENSITIVE DOCUMENTS}

Here, we may say that the conception of the provisions of Article 9 governing the treatment of sensitive documents is a relatively complex one. It can be considered a standard one requiring no relevant amendments.

13 Komárek (2012) 323-37.

14 Molek (2012) 338-53. 


\section{ACCESS TO DOCUMENTS, REGISTERS AND PUBLICATION IN THE OFFICIAL JOURNAL}

Article 10 describes the access to documents on the basis of a submitted application when the documents are made available to the applicant for inspection on the spot or by receiving a copy, including an electronic one, in dependence on the document size and according to the applicant's preference. The authority may, in the case of an existing public disclosure of the requested document, tell the applicant how he or she may obtain the requested document. If the applicant prefers, the document may be provided in the form of Braille, which is not expressly guaranteed in the Czech legislation and this can be considered as a more proactive legislative approach towards visually impaired applicants.

Article 11 regulates the functioning of registers which each EU institution should operate with respect to the effective utilization of access to documents by those interested in EU documents. With regard to the fact that this requirement does not carry any penalty, contracts concluded by EU institutions within the framework of public procurement are not mandatorily published by them as it is the case in the Slovak legislation, among others.

Direct access in electronic form or through a register is guaranteed in Article 12. The Article mainly deals with access to legislative documents (e.g. the documents originating in the legislative process) but 'where possible, other documents, notably documents relating to the development of policy or strategy, should be made directly accessible'.

In our opinion, it is a pity that in the list of examples of 'other documents' the EU legislators did not, for instance, include minutes of meetings of EU institutions, aide memoires, evaluation reports of submitted projects for funding, contracts concluded in tenders (public procurements) of EU institutions, correspondence of EU institutions with external entities, etc. Democratic control would be clearly strengthened by that. The interest of the general public, or at least the media, in the EU agenda would also be supported.

What may be considered quite problematic is the wording of Art. 12, Para. 4: 'Where direct access is not given through the register, the register shall as far as possible indicate where the document is located.'

Either the requested document is available for publication and therefore must be included in the register, or it is not accessible and then that provision of the Regulation does not make sense. Perhaps the legislators had in mind a situation where the document only exists in paper form (i.e. there does not exist a digitalized version yet) and the electronic register would at least refer to its physical location (e.g. the EU archives or library).

The enumeration of information documents that the EU institutions are required to publish in the Official Journal can be found in Art. 13.

This article in its third paragraph also states that each EU institution may in its rules of procedure establish what other documents shall be published in the Official Journal. This third paragraph can have a rather counterproductive effect. As each institution determines what else will be published in the Journal it may be misleading to the public because a regular reader of the Official Journal need not realize that, for example, the given institution is the only one that voluntarily publishes an extra document in the Journal (e.g. audit report, annual report) and he/she will expect that other institutions, too, are required to disclose that type of document in the Official Journal. This third paragraph should be abolished or a uniform procedure should be established within the inter-institutional coordination. Furthermore, this provision should rather be part of the Decision No. 2009/496/EC governing the functioning of the Official Journal. It is true that the European Commission, in the related implementing act of its decision of 5 December 2001 amending its rules of 
procedure (the Commission Decision 2001/937/EC, ECSC, Euratom of 5 December 2001 amending its Rules of Procedure) in Art. 9 of the Annex to the Decision, makes a list of its documents directly accessible to the public. This provision applies to documents drawn up or received since the effective date of the Regulation No. 1049/2001 (EC). In the above mentioned decision, the European Commission in fact mentions most of the documents that are already explicitly mentioned in the Regulation No. 1049/2001 (EC) or it is obvious from the wording of the Regulation that this type of document should be published by EU institutions.

If a document is requested which according to the statement of the applied institution does not exist, pursuant to the EU case law a rebuttable presumption of legality will be associated with such statement. ${ }^{15}$

\section{FINAL PROVISIONS OF THE REGULATION}

The last six articles, Articles 14-19, govern general measures that should be adopted by institutions to smoothly implement the objectives of Regulation No. 1049/2001 (EC).

Articles 14 and 15 establish that 'each institution shall take the requisite measures to inform the public of the rights they enjoy under this Regulation' and institutions should develop 'good administrative practices in order to facilitate the exercise of the right of access guaranteed by this Regulation' with the help of an interinstitutional committee established by the institutions for that purpose.

It is illogical that instead of Article 4, which governs exceptions when access to documents may be denied it is Article 16 that establishes that 'this Regulation shall be without prejudice to any existing rules on copyright which may limit a third party's right to reproduce or exploit released documents'. This illogical inclusion of protection of rights of third parties may weaken the knowledge of the wording of this Regulation because it is logical that the reader looking for reasons for denial of access to documents would only look for them only in one article (probably in Article 4 which can be found at the beginning of the Regulation).

The duty of institutions to publish annual reports in which they disclose the number of cases in which they refused to grant access to documents, the reasons for such refusals and the number of sensitive documents not recorded in the register is similar to the duty established in the Czech legislation. Compared to the Czech legislation it is worth noting that the EU regulation requires disclosure of the number of sensitive documents not recorded in the register. Nevertheless, it is questionable what the public may do with such information. At most, it may be interesting to compare the numbers in time and speculate what may be behind the changes of those numbers over the years.

Alternatively, unlike the Czech legislation on free access to information, the EU legislation does not impose a duty on EU institutions to annually publish the number of complaints and appeals filed against decisions not to grant the requested document, or to publish information about related court proceedings (a transcript of significant parts of each court judgment and related information as defined by Act No. 106/1999), or to publish a list of exclusive licenses granted, including justification of the necessity of granting an exclusive

15 See e.g. the joint Cases T-110/03, T-150/03 and T-405/03 Jose Maria Sison v Council of the European Union [2007] ECR II-01429 and Case T-380/04 Terezakis v. EC Commission [2008] ECR II-00011. 
license. These annual duties of Czech authorities, which have not been imposed on EU institutions yet, could become an inspiration for future EU legislation and obligatory for EU institutions, as well.

\section{CONCLUSION}

As indicated in the introduction, there undoubtedly are reasons for a reform of the EU Regulation in question and we will see what direction the future EU legislation will take.

For the time being, we may say with caution that the Czech legislation is better in some respects than the EU legislation and it does not matter if we see it as applicants for information or the institutions providing the relevant information.

This, of course, does not mean that the current Czech legislation does not have any drawbacks. We should be aware that the more complex the text is the more dangers of discontent it contains and such a danger should not be underestimated by the authors of the constitutional project. ${ }^{16}$

In the end, we may say that both the EU and Czech legislation on free access to information have made a big step forward in the past fifteen years, especially when we remember that previously there was no specific legislation at all. Nevertheless, there is still a lot of room for improvement as outlined above.

As the great Czech playwright and subsequently president Vaclav Havel once aptly said, He who really wants something is looking for a way to do it, he who does not is looking for a reason.

\section{LITERATURE}

Filip, J., Vybrané kapitoly ke studiu ústavního práva (Selected Chapters on Constitutional Law) (1st edn, Masaryk University 1997).

Kolman, P., Právo na informace (Right to Information) (1st edn, Masaryk University 2010).

Komárek, J., 'Czech Constitutional Court Playing with Matches: the Czech Constitutional Court Declares a Judgment of the Court of Justice of the EU Ultra Vires; Judgment of 31 January 2012, Pl. ÚS 5/12, Slovak Pensions XVII' (2012) 8/2 European Constitutional Law Review 323-37.

Křepelka, F., Přenos, doprovod a zohledněni evropského práva českým právem (Transfer, Accompaniment, and Consideration of European Law with Czech Law) (1st edn, Masaryk University 2010).

Kudrna, J., 'Two Preambles in the Czech Constitutional System' (2011) 52/1 Acta Juridica Hungarica $19-28$.

Lenaerts, K., 'In the Union We Trust: Trust-Enhancing Principles of Community Law' (2004) 41/2 Common Market Law Review 317-43.

Molek, P., 'Czech Constitutional Court Unconstitutionality of the Czech Implementation of the Data Retention Directive; Decision of 22 March 2011, Pl. ÚS 24/10' (2012) 8/2 European Constitutional Law Review 338-53.

Novák, D., Problémy ochrany soukromí a osobnich údajů v právu EU (Issues of Privacy and Personal Data in the EU Law) (Dissertation, Masaryk University 2012).

Paprocka, A. \& Ziółkowski, M., 'Advisory Opinions Under Protocol No. 16 to the European Convention on Human Rights' (2015) 11/2 European Constitutional Law Review 274-92.

Whitman, J.Q., 'The Two Western Cultures of Privacy: Dignity versus Liberty' (2004) 113/6 Yale Law Journal 1151-221.

16 Kudrna (2011). 


\section{LINKS}

1. Now Online - EU negotiating texts in TTIP (2015) <www.trade.ec.europa.eu/doclib/press/index. cfm?id=1230> accessed 23 December 2015.

2. WikiLeaks nabízí 100 tisíc dolarů za podrobnosti k TTIP. Přispěl i Varufakis' [WikiLeaks offers $\$ 100,000$ for details of TTIP. A contribution by Varufakis] $(2015)<$ www.euractiv.cz/obchod-aexport0/clanek/wikileaks-nabizi-100-tisic-dolaru-za-podrobonosti-k-ttip-prispel-i-varufakis012831> accessed 23 December 2015. 